\title{
Conditions of formation of seismogenic landslides on Sakhalin Island
}

\author{
Nikolay Kazakov ${ }^{1, *}$ and Sergey Kudryavtsev ${ }^{2}$ \\ ${ }^{1}$ Special Design Bureau for Marine Research Automation Tools of the Far Eastern Branch of the \\ Russian Academy of Sciences , 25 Gorkogo St., Yuzhno-Sakhalinsk, 694023, Russia \\ ${ }^{2}$ Far Eastern State Transport University, Khabarovsk, Russia
}

\begin{abstract}
There is no direct connection between landslide and seismic processes. The increase in humidity of rocks during a long period of high humidity (6-7 years) with a large amount of precipitation causes an increase in the humidity of rocks in landslides to the upper limits of plasticity (or fluidity) of soils, which leads to a decrease in their stability and activation of landslide processes. The consequence of reducing the stability of landslide arrays is to increase the probability of activation of landslide processes under seismic effects on landslide arrays. Strong hydration of rocks during the previous cycle of high humidity is maintained for at least 2 years. Therefore, in the first 2 years after the beginning of the low humidity cycle, the conditions for the activation of landslide processes in an earthquake remain. Similarly, in the first 2 years after the beginning of the high-water cycle, the rocks of landslide massifs are still not sufficiently moistened, and the probability of landslides formation in earthquakes is low. Long-term forecast of seismogenic landslides can be made as a forecast of periods of increased risk of landslides based on the account of the cycles of moisture (increase in precipitation) and physical and mechanical characteristics of rocks of landslides.
\end{abstract}

\section{Introduction}

Sakhalin Island is one of those regions of Russia where landslide hazard for the population are very high. The high intensity of landslide processes is due to the relief of Sakhalin Island (young mountains with steep slopes), the geological structure of the territory (unstable rocks - siltstones, sandstone and mudstones - are easily destroyed and involved in landslides) and a large amount of precipitation.

The relief of Sakhalin Island forces to place settlements, economic and industrial facilities, highways and other infrastructure in landslide-prone areas: in the bottoms of narrow mountain valleys and on the surface of low sea terraces under the slopes of high abrasion-denudation terraces.

The territory of the Sakhalin Island earthquake. Seismic processes can lead to the activation of landslide processes.

\footnotetext{
*Corresponding author: kazakovna@fegi.ru
} 
The cases of landslides during earthquakes was describes, but the issue of the conditions of formation of seismogenic landslides is not investigated. Not investigated the question of the possibility of forecasting the seismogenic landslides.

\section{Landslides on Sakhalin Island}

The vulgar prevalence of the territory of Sakhalin Island landslide processes reaches $70 \%$. Landslide processes develop mainly in breeds of Cretaceous, Palaeogene and Neogene age $[1,2]$.

According to the characteristics of rocks, the mechanism of landslide formation, the size and power of landslides on Sakhalin Island, there are 4 main types of landslides:

1. Block landslides and landslides-landslides on weakly weathered fractured rocks (siltstones, sandstones) with a rock depth of $8-10 \mathrm{~m}$ to $30 \mathrm{~m}$ and more and a volume of more than 1.0 million $\mathrm{m}^{3}$. So, the volume of block landslides on the Eastern coast of Sakhalin (Terpeniya Bay) exceed $5000000 \mathrm{~m}^{3}$ at a thickness of landslide slopes up to $200 \mathrm{~m}$. In the landslide process involved eluvial-deluvial sediments and the bedrock. The most intensive landslide processes are developing on the sea coasts in clay rocks. In rock areas of intense landslides, as a rule, confined to active tectonic disturbances.

2. Landslides viscoplastic flow (Fig. 1), developing in strongly weathered glinosolomennym the surface sediments. The length of landslide massifs - from tens to hundreds of meters, the volume-more than 1.0 million $\mathrm{m}^{3}$ : for example, the volume of active landslide flow between p. Ilyinsky-Belinskoye on the West coast of Sakhalin Island (Tatar Strait) is- $1500000-2000000 \mathrm{~m}^{3}$ at power up to $16,0 \mathrm{~m}$.

3. Landslides-streams. The most intensively developed in sublimirovanny sandyargillaceous rocks.

4. Surface landslides-earthflow. These are small low-power modern landslides developing in water-saturated slope deluvial deposits or on bodies of ancient landslides (Fig. 2).

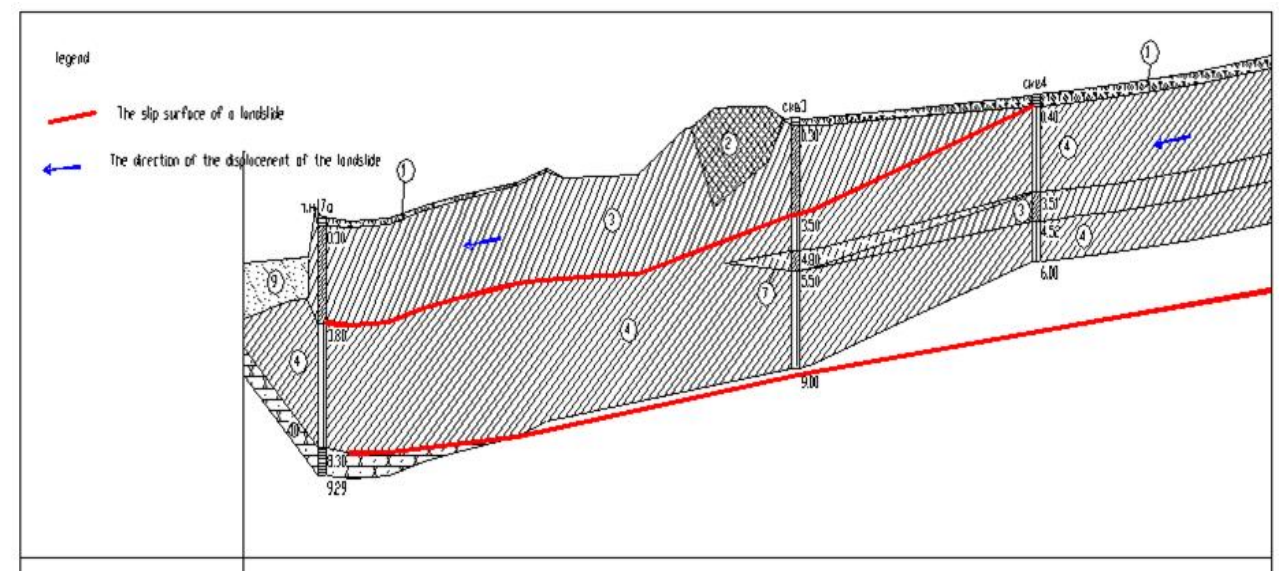

Fig. 1. Engineering-geological section of the viscoplastic flow landslide. The Western coast of Southern Sakhalin. 


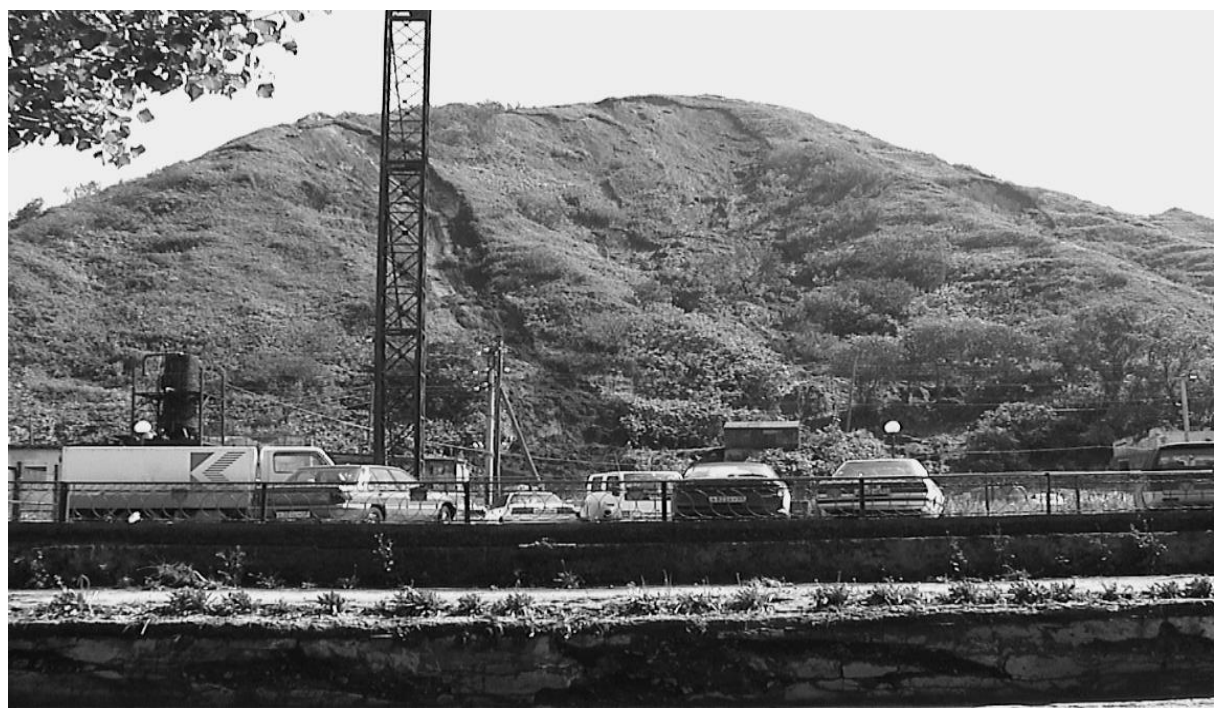

Fig. 2. Surface landslides-earthflow on the slopes of marine terraces. The West coast of Sakhalin Island.

\section{Landslide process Mode}

In the annual cycle of landslides there are two periods of active formation of landslides: the end of may - beginning of June and August-October. The first peak landslide activity caused by the peculiarities of formation of surface landslides-earthflow: in may - June, the activation of landslide processes is due to waterlogged soils of landslide massifs due to spring snowmelt.

Every $10-12$ years there is a mass formation of landslides. Periods of mass landslide formation are observed from the second half of July to the end of October and are usually associated with the passage of deep cyclones, accompanied by heavy precipitation (more than $50 \mathrm{~mm} /$ day) with a high intensity of their loss. Mandatory condition - pre-moistening of soils in landslide areas. The mass formation of landslides on Sakhalin was noted in 1875, 1928, 1954, 1964, 1970, 1976, 1978, 1981, 1992, 1993, 2002, 2003, 2009, 2010, 2011, 2018 d.

\section{Categories of landslide danger}

According to the expected nature of the impact of landslide processes on objects, structures and territories of settlements of the Sakhalin region, 9 categories of landslide complexes are allocated (table 1).

The classification was developed based on the nature of the manifestation of landslide processes on the territory of the Sakhalin region.

In assessing the impact of landslide on objects, structures and urban areas, the impact rate was taken into account, depending on the speed of the landslide and leading to either rapid destruction of objects and structures (within a few minutes) or to slow (within tens of days months) deformations of objects and structures. The impact area of the landslide on the residential or recreational area was also taken into account, i.e. the scale of probable damage during the formation of the landslide was estimated. 
Table 1. Landslide processes on Sakhalin Island.

\begin{tabular}{|c|c|c|c|c|c|c|c|}
\hline \multirow[b]{2}{*}{ 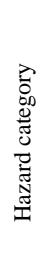 } & \multicolumn{4}{|c|}{ Characteristics of landslides } & \multicolumn{3}{|c|}{$\begin{array}{l}\text { The impact of the landslide on the objects, } \\
\text { buildings and residential areas }\end{array}$} \\
\hline & $\begin{array}{l}\text { Type of landslide } \\
\text { on the mechanism of } \\
\text { landslide formation }\end{array}$ & 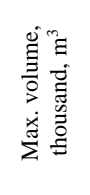 & 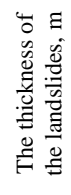 & 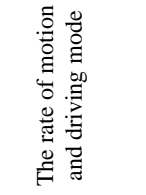 & $\begin{array}{l}\text { The nature of } \\
\text { the impact }\end{array}$ & 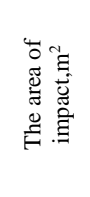 & Damage \\
\hline I & Block & $\begin{array}{l}300,0- \\
5000,0\end{array}$ & $\begin{array}{l}50,0- \\
200,0\end{array}$ & $\begin{array}{l}\text { A quick } \\
\text { shift }\end{array}$ & $\begin{array}{c}\text { Rapid } \\
\text { destruction }\end{array}$ & $\begin{array}{l}\text { Large } \\
>10000\end{array}$ & \multirow{4}{*}{$\begin{array}{l}\text { Destruction of } \\
\text { capital reinforced } \\
\text { concrete structures } \\
\text { of the I level of } \\
\text { protection and } \\
\text { linear structures of } \\
\text { underground } \\
\text { laying }\end{array}$} \\
\hline II & $\begin{array}{l}\text { Viscoplastic flow in the } \\
\text { surface sediments. }\end{array}$ & $\begin{array}{l}300,0- \\
3000,0\end{array}$ & $\begin{array}{l}15,0- \\
50,0\end{array}$ & $\begin{array}{l}\text { Slow } \\
\text { offset }\end{array}$ & $\begin{array}{l}\text { Slow } \\
\text { deformation } \\
\text { followed by } \\
\text { destruction }\end{array}$ & $\begin{array}{l}\text { Large } \\
>10000\end{array}$ & \\
\hline III & Landslide-stream. & $\begin{array}{l}300,0- \\
2000,0\end{array}$ & $\begin{array}{l}5,0- \\
40,0\end{array}$ & $\begin{array}{l}\text { Viscoplastic } \\
\text { flow. } \\
\text { Pulsing mode. }\end{array}$ & $\begin{array}{l}\text { Slow } \\
\text { deformation } \\
\text { followed by } \\
\text { destruction }\end{array}$ & $\begin{array}{c}\text { Limited } \\
5000- \\
10000\end{array}$ & \\
\hline IV & $\begin{array}{l}\text { Secondary block on the } \\
\text { bodies of ancient } \\
\text { landslides. } \\
\text { Block on marine abrasive- } \\
\text { denudation and } \\
\begin{array}{l}\text { accumulative and river } \\
\text { terraces. }\end{array}\end{array}$ & $\begin{array}{l}50,0- \\
300,0\end{array}$ & $\begin{array}{c}15,0- \\
50,0\end{array}$ & $\begin{array}{l}\text { A quick } \\
\text { shift }\end{array}$ & $\begin{array}{c}\text { Rapid } \\
\text { destruction }\end{array}$ & $\begin{array}{c}\text { Limited } \\
5000- \\
10000\end{array}$ & \\
\hline $\mathrm{V}$ & $\begin{array}{l}\text { Secondary block on the } \\
\text { bodies of ancient } \\
\text { landslides. } \\
\text { Block on marine abrasive- } \\
\text { denudation and } \\
\begin{array}{l}\text { accumulative and river } \\
\text { terraces. }\end{array}\end{array}$ & $\begin{array}{c}10.0- \\
50.0\end{array}$ & $\begin{array}{c}10.0- \\
15.0\end{array}$ & $\begin{array}{l}\text { A quick } \\
\text { shift }\end{array}$ & $\begin{array}{c}\text { Rapid } \\
\text { destruction }\end{array}$ & $\begin{array}{l}\text { Small } \\
1000- \\
5000\end{array}$ & \multirow{3}{*}{$\begin{array}{l}\text { Destruction of } \\
\text { wooden and cinder } \\
\text { block structures of } \\
\text { the II and III level } \\
\text { of protection and } \\
\text { linear structures of } \\
\text { ground and } \\
\text { aboveground } \\
\text { laying; } \\
\text { damage } \\
\text { reinforced } \\
\text { concrete structures }\end{array}$} \\
\hline VI & $\begin{array}{l}\text { Block on marine } \\
\text { abrasive-denudation and } \\
\text { accumulative and river } \\
\text { terraces. }\end{array}$ & $\begin{array}{l}3.0- \\
10.0\end{array}$ & $\begin{array}{l}3.0- \\
10.0\end{array}$ & $\begin{array}{l}\text { A quick } \\
\text { shift }\end{array}$ & $\begin{array}{c}\text { Rapid } \\
\text { destruction }\end{array}$ & $\begin{array}{l}\text { Small } \\
1000- \\
5000\end{array}$ & \\
\hline VII & $\begin{array}{l}\text { Viscoplastic flow in } \\
\text { unconsolidated sediments } \\
\text { and accumulation of } \\
\text { marine and river terraces. }\end{array}$ & $\begin{array}{l}5,0- \\
30,0\end{array}$ & $\begin{array}{l}3,0- \\
10,0\end{array}$ & $\begin{array}{l}\text { Slow } \\
\text { offset }\end{array}$ & $\begin{array}{l}\text { Slow } \\
\text { deformation } \\
\text { followed by } \\
\text { destruction }\end{array}$ & $\begin{array}{l}\text { Small } \\
1000- \\
5000\end{array}$ & \\
\hline VIII & $\begin{array}{l}\text { Surface landslides- } \\
\text { earthflow }\end{array}$ & $\begin{array}{c}0.1- \\
3.0\end{array}$ & $\begin{array}{l}\text { до } \\
3.0\end{array}$ & $\begin{array}{l}\text { A quick } \\
\text { shift }\end{array}$ & $\begin{array}{c}\text { Rapid } \\
\text { destruction }\end{array}$ & $\begin{array}{l}\text { Very } \\
\text { small } \\
<1000\end{array}$ & $\begin{array}{l}\text { Destruction of } \\
\text { structures of IV } \\
\text { level of protection; } \\
\text { destruction or } \\
\text { damage of wooden } \\
\text { structures; } \\
\text { damage to cinder } \\
\text { blocks } \\
\end{array}$ \\
\hline IX & $\begin{array}{l}\text { Surface landslides- } \\
\text { earthflow. } \\
\text { Landslide-collapse }\end{array}$ & - & - & - & \multicolumn{3}{|c|}{$\begin{array}{l}\text { Potential landslide hazard: currently landslide } \\
\text { processes are not manifested; with anthropogenic } \\
\text { impact (change in relief, destruction of } \\
\text { vegetation, etc.), the development of landslide } \\
\text { processes is likely }\end{array}$} \\
\hline
\end{tabular}

\section{Damage from landslide processes on Sakhalin Island}

On Sakhalin Island in landslide-prone areas there are more than 40 settlements.

The main damage caused by landslides to the economy of Sakhalin is expressed in damage and destruction of roads and Railways, communication and power lines, flooding of the territories of settlements with landslide deposits, destruction of houses and objects (Fig. $3,4)$. There are human sacrifices. 


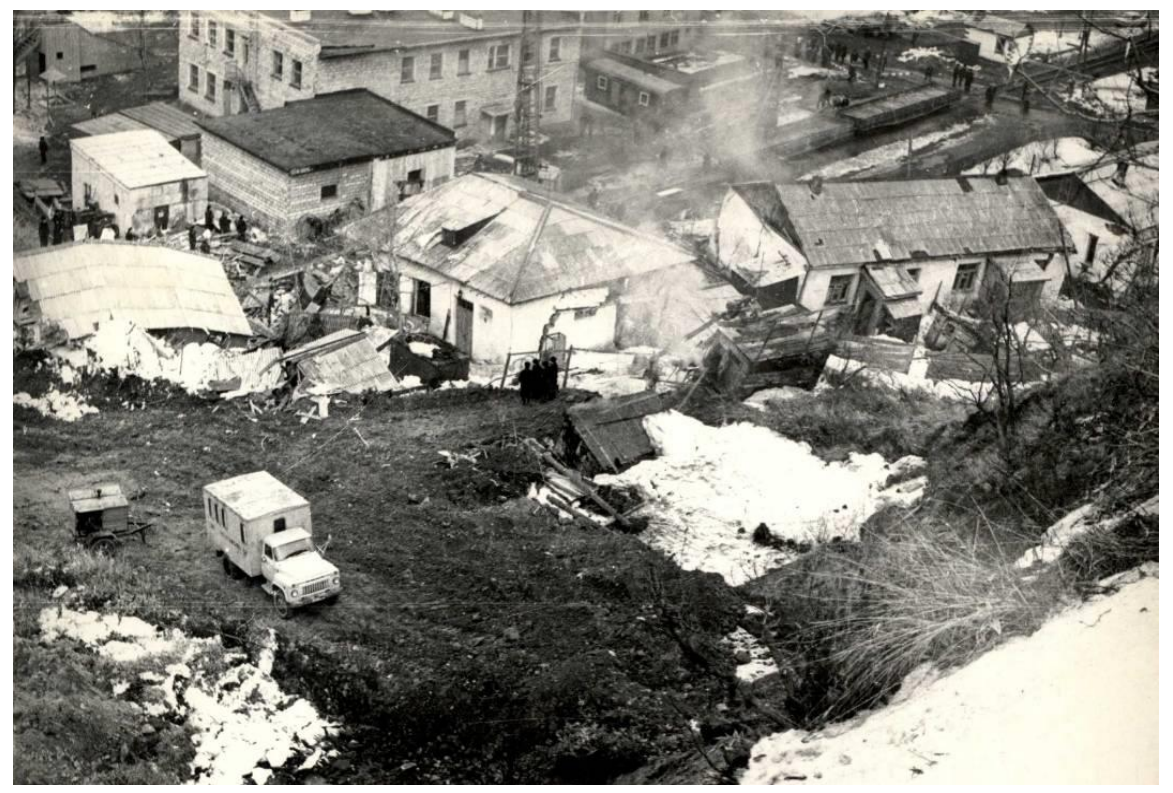

Fig. 3. The Nevelsk Town, may 1981. Landslide destroyed 5 residential houses. The West coast of Sakhalin Island.

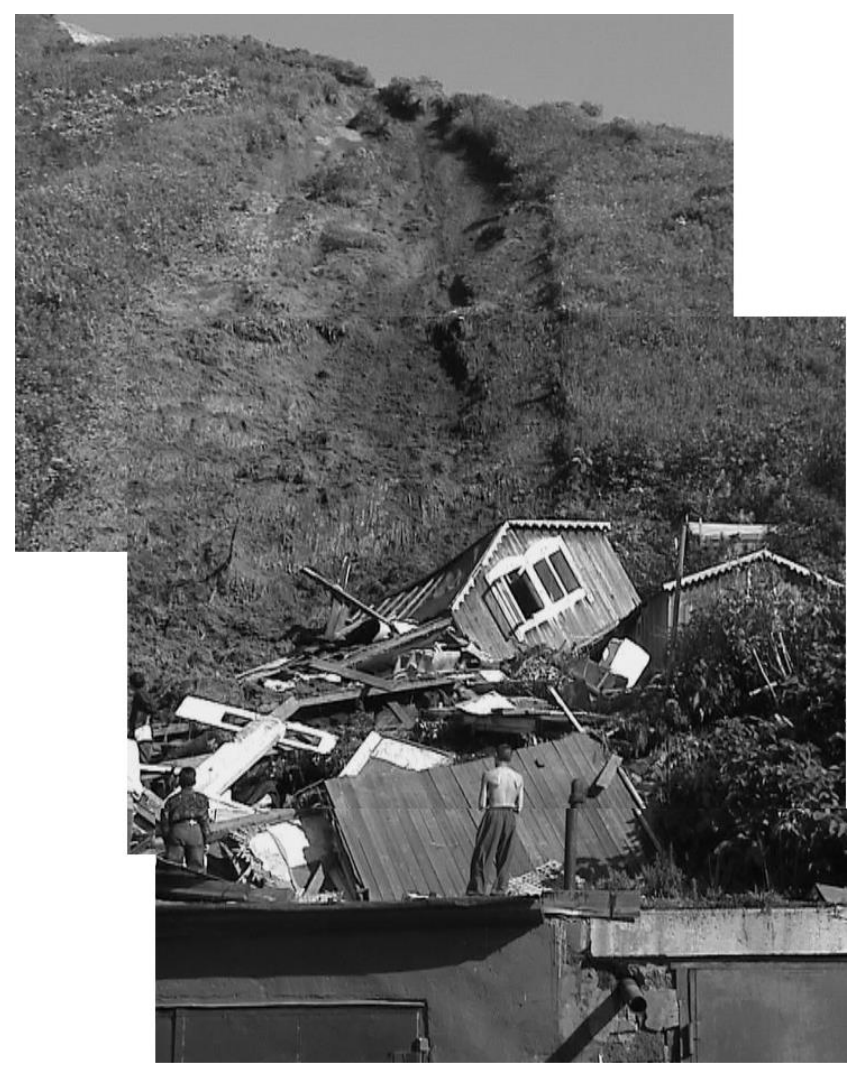

Fig. 4. Residential house destroyed by a landslide. 
In 1973 in the Makarov Town, the damaged objects of the bakery. In 1978, an anthropogenic landslide destroyed a garage in Kholmsk Town and killed a man. In may 1981 in the Nevelsk Town landslide destroyed 5 one-story houses and killed a man (Fig. 3).

The greatest damage to landslides is caused during periods of mass formation, usually caused by heavy precipitation when entering the area of deep cyclones and typhoons.

During the passage of the Typhoon "Phyllis" on August 5-6,1981 only in settlements and in the areas of economic activity in the southern and Middle Sakhalin, more than 300 landslides with a volume of up to $100000 \mathrm{~m} 3$ were registered. In Nevelsk Town, 6 houses were destroyed by landslides, 6 people were killed; several houses were destroyed by landslides in Uglegorsk Town. Landslides destroyed a total of several thousand meters of roadway, destroyed communication lines and power for several thousand meters, damaged several dozen houses. The last period of active landslide formation was observed in may 2018 in the southern regions of Sakhalin Island. Heavy precipitation and snowmelt led to the activation of landslides, which caused damage to the road Yuzhno-Sakhalinsk - Kholmsk. A landslide-flood, formed from piles of rocks. coal mining career destroyed 2 houses in Gornozavodsk village.

\section{Conditions of seismogenic activation of landslide processes on Sakhalin Island}

The seismicity of the Sakhalin Island is 6-9 points on the scale of MSK64. Seismic processes can lead to the activation of landslide processes.

Atmospheric precipitation is the most important hydrometeorological factor of the landslides formation. On Sakhalin Island the average annual rainfall for the warm period (April-October) in the valleys and on the sea shores is $400-600 \mathrm{~mm}$, in the mountains -800 $-1500 \mathrm{~mm}$. Observed maximum of liquid precipitation (altitude $470 \mathrm{~m}$ ) is $1277 \mathrm{~mm}$ in three days of rain (05 - 07.08.1981). The observed daily maximum of liquid precipitation is 230 $\mathrm{mm}$. In case of strong earthquakes (especially after periods of long-term moistening of rocks) both in the mountainous and in the coastal part of Sakhalin Island block landslides with a volume of more than 5 million $\mathrm{m}^{3}$ can be formed.

A prerequisite for the seismic activation of landslide processes on Sakhalin Island is the pre-moistening of rock landslide massifs (block landslides, landslides viscoplastic flow and landslides-flows), as a result of which the stability of landslide massifs is greatly reduced due to the approximation of the soil to the limits of plasticity( fluidity), and in the rock massifs (block landslides) - due to the flooding of contacts between the layers of rocks (with their concordant occurrence), resulting in the contacts of layers the slip surface of the landslide is formed. The same processes form the sliding surfaces on the contacts of the layers in those landslide arrays, in which the landslides of the viscoplastic flow are formed.

Such conditions occur during periods of long-term hydration of rocks: at the end of the cycle of increased moisture - at the beginning of the cycle of reduced moisture.

To determine the frequency of occurrence of conditions causing mass formation of landslides, we analyzed the data on the amount of precipitation at hydrometeorological stations with long-term series of observations (more than 80 - 100 years) for precipitation.

In the age-old cycle of humidification on Sakhalin island, 5 large cycles with a period of 17-21 years are allocated, which in turn are divided into 14 small cycles with a period of 6-7 years [3]. Significant variations in precipitation occur from year to year, but cycles with significant rainfall alternate with cycles with low rainfall. These cycles coincide with the periods of mass activation of landslide processes. A comparison of precipitation data with data on the periods of mass landslide formation showed the following. 
The greatest number of periods of mass activation of landslides falls on the cycle of the greatest moisture (1955-1973) - 9 cases. The next cycle of small hydrate (1971-1977 gg) of these cases only 3.

From 2000 to 2012, 4 cases of mass activation of landslides were recorded in southern Sakhalin: at the end of the cycle of increased moisture in 2002 (during the Typhoon "Chataan"), in the cycle of increased moisture in June-August 2009, in August 2010, in August-September 2012 and in may 2018. All these periods of activation of landslide processes are associated with the geological structure of the territory, which determines the characteristics of rocks in landslide complexes. Thus, on the South-East coast of Sakhalin Island on the surface of the day out weak sandstones of the maruyam Suite, composing the base of a high sea terrace (height 20-60 m) and having low strength characteristics. Due to the weak resistance to weathering, rocks are easily decompressed from the surface (to a depth of 2-3 m) to sandy loam and sand, which makes them mobile when saturated with water. Significant steepness (up to $40-50^{\circ}$ ) of the abrasion ledge and its strong dissection by erosion cuttings also contributed to the formation of landslides, of which surface landslides-earthflow prevailed. The volume of surface landslides-earthflow was 50-70 $\mathrm{m}^{3}$ descended, length 20 $40 \mathrm{~m}$, width $-2.5-7.0 \mathrm{~m}$, depth of capture species - from 1.0 to $2.0 \mathrm{~m}$.

Large landslides on the road Yuzhno-Sakhalinsk - Okha caused a drawdown of the roadway on $0,6-0,7 \mathrm{~m}$ the Length of the landslide circus, which captured the road reached $120 \mathrm{~m}$. On the Western coast of Sakhalin Island occurred surface landslides-earthflow much larger - up to $1000 \mathrm{~m}^{3}$.

Since 2003, the amount of precipitation over the territory of Sakhalin Island has decreased and its values are close to the minimum observed from the mid-40s to the early 50s of the twentieth century. In 2008, a 6-year cycle of low moisture ended. According to observations of precipitation in 2008-2012, the amount of precipitation exceeded the average annual values. So, on the West coast of Sakhalin Island fell $948 \mathrm{~mm}$ of precipitation. At the same time, in the winter of $2008-09,140 \%$ of the average annual precipitation for this area fell, with the amount of precipitation in March 2009 exceeded the average values by $100 \%$, and the amount of precipitation in July 2010 was $260 \mathrm{~mm}$, which exceeds the average values by $200 \%$. Thus, for the previous two years in the soils of potential landslide complexes, a significant reserve of moisture was accumulated. The cold, protracted spring of 2011, led to excessive water logging of soils and caused activation of landslide processes. In the cycle of strong moisture 2009 - 2017 in southern Sakhalin, 6 periods of mass landslide formation were observed: in June, July and August 2009, in August 2010, in August and September 2012.

Landslides caused the destruction of roads and Railways and damage to buildings in the cities and villages of the settlements of southern Sakhalin Island. Thus, the increased moisture of rocks during the long-term period of increased moisture with a large amount of precipitation causes an increase in the humidity of rocks in the landslide massifs to the upper limits of plasticity (or fluidity) of soils, which leads to a decrease in their stability and activation of landslide processes. The consequence of reducing the stability of landslide arrays is to increase the probability of activation of landslide processes under seismic effects on landslide arrays. However, strong hydration of rocks during the previous cycle of increased moisture is maintained for at least 2 years. Therefore, in the first 2 years after the beginning of the cycle of low moisture activity of landslide processes remains. At the same time, the conditions for the activation of landslide processes in an earthquake remain. Thus, in 2018 , the cycle of reduced moisture began. However, due to the high humidity of rocks in the landslide areas led to the mass formation of landslides in southern Sakhalin in may 2018, which caused the destruction of roads and houses. Similarly, in the first 2 years after the start of the high-moisture cycle, the rocks of landslide massifs are not yet sufficiently moistened, and the probability of landslides formation during earthquakes is low. 


\section{Forecast of seismic activation of landslide processes on Sakhalin Island}

A long-term forecast of seismogenic landslides can be made as a forecast of periods of increased risk of landslides. Such a forecast can be developed on the basis of taking into account the cycles of moisture (increased amount of precipitation) and physical and mechanical characteristics of rocks of landslide massifs.

During the cycle of increased moisture due to the increased amount of precipitation is an increase in the humidity of rocks in the landslides, which, as a result, leads to a decrease in their stability and to the activation of landslide processes.

The consequence of reducing the stability of landslide arrays is to increase the probability of activation of landslide processes under seismic effects on landslide arrays.

In the period of 2018 - 2023 in southern Sakhalin, the activation of landslide processes in earthquakes is likely under the following conditions (table 2):

- in 2018, block landslides of large volumes are likely to form during earthquakes of 4-5 points or more: especially during and after heavy rains;

- after 2019, the probability of landslide processes activation in earthquakes with a force of less than 7 points will decrease;

- in 2018, surface landslides-earthflow of small volume can be formed everywhere in case of earthquakes with a force of more than 4 points occurring during and after heavy rains;

- after 2018, the probability of landslide processes activation in earthquakes with a force of less than 7 points will decrease.

Table 2. conditions of seismic activation of landslide processes on Sakhalin Island 2018-2023.

\begin{tabular}{|c|c|c|c|c|c|c|}
\hline \multirow{2}{*}{ 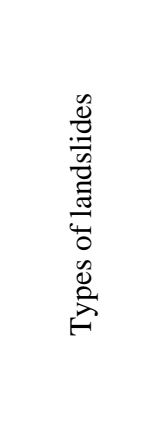 } & \multirow{2}{*}{ 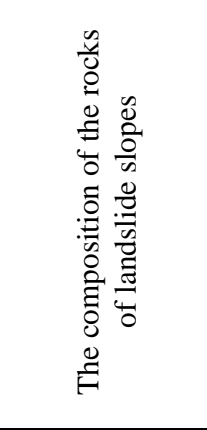 } & \multirow{2}{*}{ 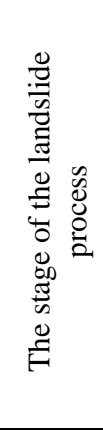 } & \multicolumn{2}{|c|}{$\begin{array}{l}\text { The conditions of } \\
\text { hydration of rocks of } \\
\text { landslide slopes }\end{array}$} & \multicolumn{2}{|c|}{$\begin{array}{c}\text { Earthquake } \\
\text { intensity that causes } \\
\text { the activation of } \\
\text { landslide processes, } \\
\text { point }\end{array}$} \\
\hline & & & $\begin{array}{c}\text { Long } \\
\text { (in a } \\
\text { multi-year } \\
\text { cycle of } \\
\text { increased } \\
\text { moisture), } \\
\text { years }\end{array}$ & $\begin{array}{c}\text { Short } \\
\text { (intensive } \\
\text { liquid and } \\
\text { mixed } \\
\text { precipitation), } \\
\text { days }\end{array}$ & 2018 & $\begin{array}{c}2019- \\
2023\end{array}$ \\
\hline $\begin{array}{l}\text { Surface } \\
\text { landslides- } \\
\text { earthflow. }\end{array}$ & $\begin{array}{l}\text { Cohesive soils } \\
\text { with the } \\
\text { inclusion of } \\
\text { crushed stone } \\
\text { and gravel } \\
\text { (slope } \\
\text { deposits) }\end{array}$ & Active & $2-3$ & $1-15$ & $\geq 4$ & $\geq 7$ \\
\hline $\begin{array}{l}\text { Block } \\
\text { landslides }\end{array}$ & $\begin{array}{l}\text { Mudstone, } \\
\text { siltstone, } \\
\text { sandstone }\end{array}$ & Active & $3-5$ & - & $\geq 5$ & $\geq 6$ \\
\hline $\begin{array}{l}\text { Block } \\
\text { landslides }\end{array}$ & $\begin{array}{l}\text { Mudstone, } \\
\text { siltstone, } \\
\text { sandstone }\end{array}$ & Active & $2-3$ & $1-15$ & $\geq 3$ & $\geq 5$ \\
\hline $\begin{array}{l}\text { Block } \\
\text { landslides }\end{array}$ & $\begin{array}{l}\text { Mudstone, } \\
\text { siltstone, } \\
\text { sandstone }\end{array}$ & Active & $1-2$ & $1-15$ & $\geq 2$ & $\geq 5$ \\
\hline
\end{tabular}




\begin{tabular}{|l|l|l|l|c|c|c|}
\hline $\begin{array}{l}\text { Block } \\
\text { landslides }\end{array}$ & $\begin{array}{l}\text { Mudstone, } \\
\text { siltstone, } \\
\text { sandstone }\end{array}$ & Inactive & $3-5$ & - & $\geq 5$ & $\geq 7$ \\
\hline $\begin{array}{l}\text { Surface } \\
\text { landslides- } \\
\text { earthflow. }\end{array}$ & $\begin{array}{l}\text { Anthropogenic } \\
\text { soils on the } \\
\text { waste rock } \\
\text { dumps: clay } \\
\text { formation with } \\
\text { the inclusion } \\
\text { of crushed } \\
\text { stone Inactive }\end{array}$ & $3-5$ & $2-15$ & $\geq 5$ & $\geq 5$ \\
\hline
\end{tabular}

\section{Discussion and conclusions}

Such ideas about the conditions of the seismogenic activation of landslide processes on the Sakhalin Island are confirmed by observations during the Nevelsk earthquake in August 2007 (magnitude of 6.2): a strong earthquake that occurred at the end of the cycle of low moisture, has caused the formation of landslides in the area of the earthquake.

But there is no direct relationship between landslide and seismic processes.

The increased moisture of rocks during the long-term period of increased moisture with a large amount of precipitation causes an increase in the humidity of rocks in the landslide massifs to the upper limits of plasticity (or fluidity) of soils, which leads to a decrease in their stability and activation of landslide processes.

The consequence of reducing the stability of landslide arrays is to increase the probability of activation of landslide processes under seismic effects on landslide arrays. However, strong hydration of rocks during the previous cycle of increased moisture is maintained for at least 2 years. Therefore, in the first 2 years after the beginning of the cycle of low moisture activity of landslide processes remains.

At the same time, the conditions for the activation of landslide processes in an earthquake remain.

Similarly, in the first 2 years after the start of the high-moisture cycle, the rocks of landslide massifs are not yet sufficiently moistened, and the probability of landslides formation during earthquakes is low.

A long-term forecast of seismogenic landslides can be made as a forecast of periods of increased risk of landslides. Such a forecast can be developed on the basis of taking into account the cycles of moisture (increased amount of precipitation) and physical and mechanical characteristics of rocks of landslide massifs.

During the cycle of increased moisture due to the increased amount of precipitation is an increase in the humidity of rocks in the landslides, which, as a result, leads to a decrease in their stability and to the activation of landslide processes.

The consequence of reducing the stability of landslide arrays is to increase the probability of activation of landslide processes under seismic effects on landslide arrays.

\section{References}

1. G. Polunin, Dynamics and forecast of exogenous processes (1989)

2. G. Polunin, V. Buzlaev, Lithological complexes and manifestations of exogenous processes of Sakhalin island: Map 1: 500000 (1984)

3. Yu. Gensiorovskiy, N. Kazakov, Georisk 2, 56 - 60 (2009) 